\title{
Modelling of long term nitrogen retention in surface waters
}

\author{
S. Halbfaß, M. Gebel, and S. Bürger \\ Gesellschaft für Angewandte Landschaftsforschung (GALF) bR, Dresden, Germany
}

Received: 18 January 2010 - Revised: 22 May 2010 - Accepted: 30 May 2010 - Published: 9 December 2010

\begin{abstract}
In order to derive measures to reduce nutrient loadings into waters in Saxony, we calculated nitrogen inputs with the model STOFFBILANZ on the regional scale. Thereby we have to compare our modelling results to measured loadings at the river basin outlets, considering long term nutrient retention in surface waters. The most important mechanism of nitrogen retention is the denitrification in the contact zone of water and sediment, being controlled by hydraulic and micro-biological processes. Retention capacity is derived on the basis of the nutrient spiralling concept, using water residence time (hydraulic aspect) and time-specific N-uptake by microorganisms (biological aspect). Short time related processes of mobilization and immobilization are neglected, because they are of minor importance for the derivation of measures on the regional scale.
\end{abstract}

\section{Introduction}

The nitrogen transfer in catchment areas is controlled by different interdependent processes. Nutrient sources, pathways and sinks are strongly influenced by the catchment character, hydrology and anthropogenic inputs. Most important processes of transfer are in general driven by infiltration via macropores (Bundt, 2000; Heathwaite and Dils, 2000), drainage, interflow and groundwater runoff (Kronvang et al., 1997; Pudenz, 1998; Chapman, 2001; Jonge et al., 2004), biological turnover in waters (Boulton et al., 1998; Jin et al., 2007) and nutrient inputs from point sources. Nitrogen fluxes in waters are determined by spatial and temporal dynamic described by the concept of nutrient spiraling (Stream Solute Workshop, 1990).

Correspondence to: S. Halbfaß

(stefan.halbfass@galf-dresden.de)

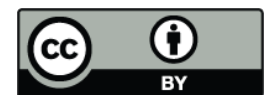

Many physical and biogeochemical factors are influencing processes, nutrient concentrations and loadings (Withers and Jarvie, 2008). Important time and space differentiated parameters are conditions of morphology, hydrology and meteorology, the bioactivity, processes in the riparian zone, river bed and inundation zone and the water management practice (Svendsen et al., 1998). While dealing with the nutrient retention phenomenon we should be aware, that many effects are short time related, especially controlled by hydrological variability (flood, low water).

The most important $\mathrm{N}$-removal is caused by denitrification in river beds (e.g. Donner et al., 2004). At the moment there is still a lack of plausible methods to derive processoriented retention rates in the meso- or macroscale catchment modelling. Our computation of an average long term retention of nitrogen in surface waters is based on generally available data and should only be used in a regional river basin modelling.

In the present contribution we focus on methodology development and results of the nitrogen retention modelling in surface waters in Saxony as part of the project "Mapping of nutrient inputs in surface waters in Saxony (Germany)", supported by Saxon State Agency of the Environment, Agriculture and Geology. Thereby we have to consider nutrient retention to compare the results of our modelling of nutrient inputs to measured loadings at the respective river basin outlets. The modelling of diffuse and point related nutrient inputs, done with the WebGIS based STOFFBILANZ software, is used by the water authorities to derive measures to reduce loadings, i.e. according to the Water Framework Directive. All information about the quantification of nutrient input within the catchment areas considering its sources and pathways is described in detail in Halbfaß et al. (2010) and Gebel et al. (2010).

Published by Copernicus Publications on behalf of the European Geosciences Union. 
Table 1. Model parameters and calibration data.

\begin{tabular}{|c|c|c|}
\hline Parameter & Description & Data origin \\
\hline River section length & Generalised river network & State Agency* \\
\hline Hydraulic gradient & $\begin{array}{l}\text { River network combined with } \\
\text { Digital elevation model (ATKIS/Q2) }\end{array}$ & State Agency* \\
\hline River width & $\begin{array}{l}\text { Standardised mean river width depending on river } \\
\text { type classification according to LAWA }\end{array}$ & State Agency*/LAWA** \\
\hline Manning-Strickler-coefficient & Depending on river type classification according to LAWA & LAWA $^{* *}$ \\
\hline Discharge and nitrogen input & $\begin{array}{l}\text { Mean annual discharge and nitrogen input, } \\
\text { simulated by STOFFBILANZ model }\end{array}$ & State Agency* \\
\hline
\end{tabular}

* Saxon State Agency of the Environment, Agriculture and Geology.

** LAWA: Länderarbeitsgemeinschaft Wasser.

\section{Retention of nitrogen in rivers}

The most important mechanism of nitrogen retention in surface waters is the denitrification in the contact zone of water and sediment, being controlled by hydraulic and micro-biological processes. According to the Nutrient Spiralling - concept (Stream Solute Workshop, 1990) modelling of retention $r_{\text {riv }}$ of a river section is done using time-specific N-uptake rate $k_{t}\left[\mathrm{~m} \mathrm{~d}^{-1}\right]$ (biological aspect) and water residence time $\tau$ (hydraulic aspect) as follows (Wollheim et al., 2006):

$r_{\text {riv }}=1-\exp \left(-k_{t} \cdot \tau\right)$

Water residence time is derived from the river section length $l$ and the average flow velocity $v$ with:

$\tau=\frac{l}{v}$

The flow velocity is generated in a simplified way according to Mischke et al. (2005), considering the hydraulic gradient $I$, discharge $Q$, river width $w$ and Manning-Stricklercoefficient $k_{\mathrm{ST}}$ :

$v=k_{\mathrm{ST}}\left(\frac{Q}{k_{\mathrm{ST}} \cdot w \cdot \sqrt{I}}\right)^{\left(\frac{2}{5}\right)} \cdot \sqrt{I}$

The N-uptake rate depends on the discharge according to literature data (Wollheim et al., 2006). Thus we have a decreasing uptake rate with an increasing discharge, because the relationship between contact zone of water and sediment and the discharge becomes more disadvantageous. River length is derived using GIS-technologies for each surface water body. The discharge of a surface water body includes the discharges of its upstream residents. Thus the whole catchment is considered. The Manning-Strickler-coefficient is taken from the mapping of river structures of Saxon State Agency of the Environment, Agriculture and Geology (see Table 1).

\section{Retention of nitrogen in lakes and reservoirs}

The retention modelling in lakes and reservoirs $r_{\text {res }}$ is done according to Maniak (2005) considering the coefficient of nitrogen net transfer $s_{\mathrm{N}}$, average depth of the water body $z$ and the hydraulic residence time $\tau$ :

$r_{\text {res }}=\frac{s_{\mathrm{N}}}{\left(s_{\mathrm{N}} \frac{z}{\tau}\right)}$

\section{Calculation within the river net}

We determine a specific retention for each surface water body (SWB). The corresponding load per SWB $L_{i}\left[\mathrm{tyr}^{-1}\right]$ consists of the catchment related input within the SWB area $\mathrm{TN}_{i}$ multiplied with the specific coefficient of retention $r$ and the sum of inputs $L_{j}$ from the upstream residents, multiplied with $r$ :

$L_{i}=\left(\mathrm{TN}_{i}+\sum L_{j}\right) \cdot(1-r)$

Tributaries and upstream residents are joined by a routing procedure to simulate the transport from the source areas to the outlet of a watershed for a one year period, reflecting the average management situation from 2000 to 2005 .

\section{Results and discussion}

The starting point of the computation of retention are the modelling results of diffuse and point related nitrogen input per grid element, described in detail in Gebel et al. (2010) and Halbfaß et al. (2010). The grid elements represent the spatial properties of a watershed area. Retention is then calculated considering the respective parameters described above. The routing of tributaries and upstream residents is realized by the help of GIS-technologies. Total nitrogen retention in saxonian rivers and reservoirs is shown in Fig. 1 with regard to the surface water body level. 
Table 2. Nitrogen inputs into surface water and loadings at selected river basin outlets in Saxony (reference year 2005).

\begin{tabular}{lccc}
\hline River basin & $\begin{array}{c}\text { Total nitrogen } \\
\text { input into } \\
\text { surface } \\
\text { water } \\
\text { [t/yr] }\end{array}$ & $\begin{array}{c}\text { Nitrogen } \\
\text { loading } \\
\text { at river } \\
\text { basin outlet }\end{array}$ & $\begin{array}{c}\text { average } \\
\text { value } \\
\text { of } \\
\text { retention }\end{array}$ \\
\hline Mulde & 15.458 & 10.138 & 34 \\
Elbe & 8.222 & 6.011 & 27 \\
Weiße Elster* & 6.270 & 4.977 & 21 \\
Spree & 2.945 & 2.280 & 23 \\
Schwarze Elster & 3.487 & 3.095 & 11 \\
Lausitzer Neiße & 1.312 & 981 & 25 \\
Saxony & 37.694 & 27.482 & 27 \\
\hline
\end{tabular}

* excluding thuringian inputs.

Table 2 shows the values of mean retention simulated for selected gauge stations in different landscape regions and the respective total nitrogen inputs (without retention) and total nitrogen loadings (including retention). According to these values retention differs from $11 \%$ to $34 \%$ of the total input. It should be considered that this mean retention value is only an integral of the different retention values in the respective tributary and all its upstream residents.

Based on the calculated retention values per surface water body we are able to derive total nitrogen loadings as shown in Fig. 2.

A comparison of calculated nitrogen loadings considering retention, and measured ones at catchment outlets is presented in Fig. 3. Calculating the $R^{2}$-value, we excluded gauging stations OBF00200 (Labe), OBF01800 (Elbe-1), OBF02810 (Elbe-2) and OBF47600 (Mulde-7) in order to avoid a statistical overweight due to high emissions and loadings of these large watershed areas. However we used these stations to calibrate the modelling $\left(r^{2}=0.90\right)$ before we started the validation procedure. Apart from that all remaining gauging stations with common datasets of discharge and nitrogen concentration have been considered. Bigger differences can be seen in the Lausitz (e.g. Spree and Schöps catchments), caused by the special conditions of runoff in the mining region as well as in regions with important influences of reservoir water management (e.g. influences of water divertion).

Finally we can conclude that the computation of long lasting retention on a regional scale, based on generally available data, has been accomplished successfully. The retention values were confirmed by our investigation and they also correspond to literature data (e.g. Seitzinger et al., 2002; Svendsen and Kronvang, 1993). Nevertheless we have to emphasize that the methodology should only be used in applications on meso- or macroscale, focusing on long term effects of retention in surface waters. At the same

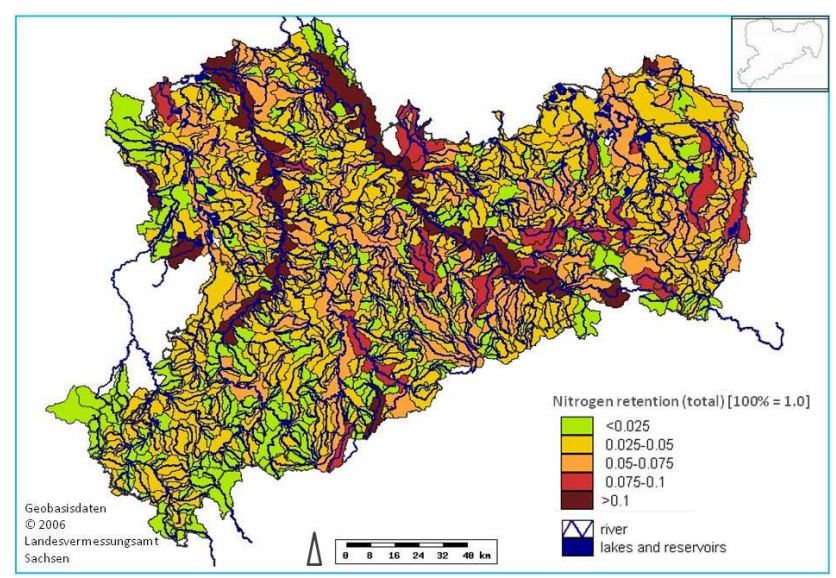

Fig. 1. Nitrogen retention in rivers and reservoirs per surface water body.

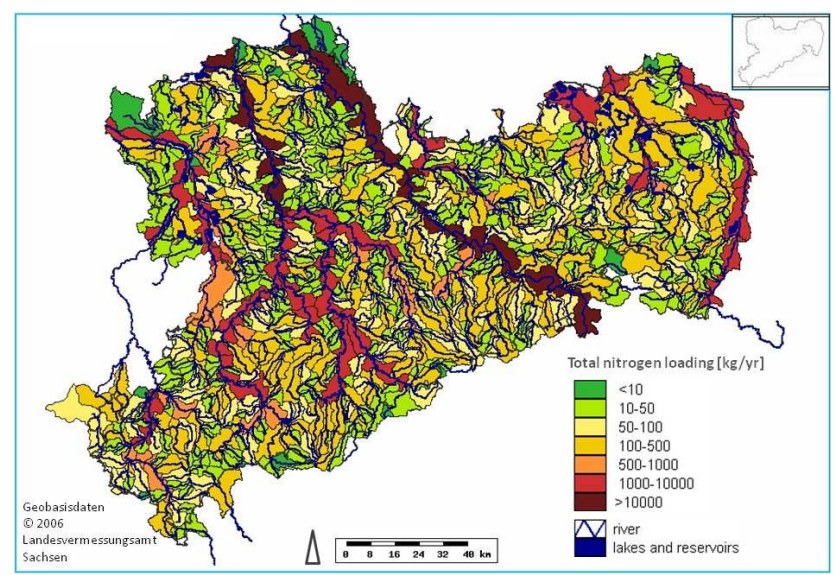

Fig. 2. Total nitrogen loading per surface water body including retention in rivers/streams and reservoirs.

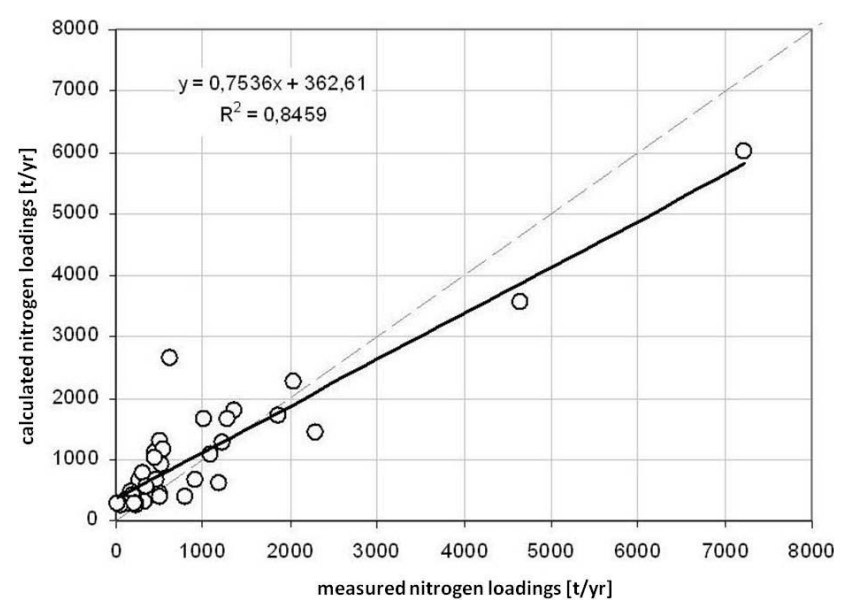

Fig. 3. Comparison of calculated and measured loadings at catchment outlets on selected gauge stations. 
time the description of spatial and temporal variability in retention modelling and nutrient transfer is limited. Short time related mobilization and immobilization of nitrogen as well as event based retention modelling is not considered in the methodology. Some improvement should be done in the near future, considering the following topic. The N-uptake rate is derived from literature, its dependency on nitrate concentration and water temperature is not considered at the moment. The implementation of these parameters should be forwardedin order to optimize the retention modelling especially for point-related inputs.

Acknowledgements. The project "Mapping of nutrient inputs in surface waters in Saxony (Germany)" was supported by Saxon State Agency of the Environment, Agriculture and Geology. We wish to thank all colleagues of the agency for intensive cooperation, support and the supply of agricultural, hydrological, chemical, soil and climate data.

Edited by: A. Wahren, F. Tavares Wahren, and K.-H. Feger Reviewed by: two anonymous referees

\section{References}

Boulton, A. J., Findlay, S., Marmonier, P., Stanley, E. H., and Valett, H. M.: The functional significance of the hyporheic zone in streams and rivers, Annu. Rev. Ecol. Syst., 29, 59-81, 1998.

Bundt, M.: Highways Through the Soil. Properties of Preferential Flow Paths and Transport of Reactive Compounds, Ph.D. thesis, Zrich, 2000.

Chapman, A. S., Foster, I. D. L., Lees, J. A., Hodgkinson, R. A., and Jackson, R. H.: Particulate phosphorus transport by subsurface drainage from agricultural land in the UK, Environmental significance at the catchment and national scale, Sci. Total Environ., 266, 95-102, 2001.

Donner, S. D., Kucharik, C. J., and Oppenheimer, M.: The influence of climate on in-stream removal of nitrogen, Geophys. Res. Lett., 31, L20509, doi:10.1029/2004GL020477, 2004.

Gebel, M., Halbfaß, S., Bürger, S., Friese, H., and Naumann, S.: Modelling of nitrogen turnover and leaching in Saxony, Adv. Geosci., 27, 139-144, doi:10.5194/adgeo-27-139-2010, 2010.

Halbfaß, S., Gebel, M., Friese, H., Grunewald, K., and Mannsfeld, K.: Atlas der Nährstoffeinträge in sächsische Gewässer, Schriftenreihe des Landesamtes für Umwelt, Landwirtschaft und Geologie (Ed.), Dresden, 2009 (in German).
Heathwaite, A. L. and Dils, R. M.: Characterising phosphorus loss in surface and subsurface hydrological pathway, Sci. Total Environ., 251/252, 523-538, 2000.

Jin, H. S., Ramsey, J. B., and White, D. S.: Nutrient Uptake and Retention Patterns in Two Streams with Contrasting Watershed Landuse, J. Ky. Acad. Sci., 68(1), 24-30, 2007.

Jonge, L. W., Moldrup, P., Rubæk, G. H., Schelde, K., and Djurhuus, J.: Particle Leaching and Particle-Facilitated Transport of Phosphorus at Field Scale, Vadose Zone J., 3, 462470, 2004.

Kronvang, B., Grant, R., and Laubel, A. L.: Sediment and phosphorus export from a lowland catchment: Quantification of sources, Water Air Soil Poll., 99, 465-476, 1997.

Maniak, U.: Hydrologie und Wasserwirtschaft - Eine Einführung für Ingenieure, Springer, Berlin Heidelberg, 2005 (in German).

Mischke, U. and Opitz, D.: Endbericht zum LAWA-Vorhaben Entwicklung eines Bewertungsverfahrens für Fließgewässer mittels Phytoplankton zur Umsetzung der EU-Wasserrahmenrichtlinie, IGB, Berlin, 2005 (in German).

Pudenz, S.: Modellierung der regionalen Phosphorverlagerung im Boden und Grundwasser, Ph.D. thesis, TU Berlin, 1998 (in German).

Seitzinger, S. P., v. Styles, R., Boyer, E. W., Alexander, R. B., Billen, G., Howarth, R. W., Mayer, B., and Van Breemen, N.: Nitrogen retention in rivers: model development and application to watersheds in the northeastern U.S.A., Biogeochemistry, 57/58, 199-237, 2002.

Stream Solute Workshop: Concepts and Methods for Assessing Solute Dynamics in Stream Ecosystems, J. N. Am. Benthol. Soc., 9(2), 95-119, 1990.

Svendsen, L. M. and Kronvang, B. K.: Retention of nitrogen and phosphorus in a Danish lowland river system: implications for the export from the watershed, Hydrobiologia, 251, 123-135, 1993.

Svendsen, L. M., Kronvang, B. K., Laubel, A. R., Larsen, S. E., and Andersen, B.: Phosphorus retention in a Danish lowland river system, Proc. Int. Assoc. Theor. Appl. Limnol./Trav. Assoc. Int. Limnol. Theor. Appl., 26(3), 956-962, 1998.

Withers, P. J. A. and Jarvie, H. P.: Delivery and cycling of phosphorus in rivers: A review, Sci. Total Environ., 400, 379395, 2008.

Wollheim, W. M., Vörösmarty, C. J., Peterson, B. J., Seitzinger, S. P., and Hopkinson, C. S.: Relationship between river size and nutrient removal, Geophys. Res. Lett., 33, L06410, doi:10.1029/2006GL025845, 2006. 